\title{
Front Matter: Volume 9354
}

, "Front Matter: Volume 9354," Proc. SPIE 9354, Free-Space Laser Communication and Atmospheric Propagation XXVII, 935401 (17 April 2015); doi: $10.1117 / 12.2193208$

SPIE. Event: SPIE LASE, 2015, San Francisco, California, United States 


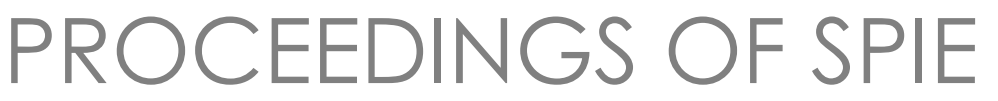

\title{
Free-Space Laser Communication and Atmospheric Propagation XXVII
}

\author{
Hamid Hemmati \\ Don M. Boroson \\ Editors
}

8-9 February 2015

San Francisco, California, United States

Sponsored and Published by

SPIE 
The papers included in this volume were part of the technical conference cited on the cover and title page. Papers were selected and subject to review by the editors and conference program committee. Some conference presentations may not be available for publication. The papers published in these proceedings reflect the work and thoughts of the authors and are published herein as submitted. The publisher is not responsible for the validity of the information or for any outcomes resulting from reliance thereon.

Please use the following format to cite material from this book:

Author(s), "Title of Paper," in Free-Space Laser Communication and Atmospheric Propagation XXVII, edited by Hamid Hemmati, Don M. Boroson, Proceedings of SPIE Vol. 9354 (SPIE, Bellingham, WA, 2015) Article CID Number.

ISSN: 0277-786X

ISBN: 9781628414448

Published by

SPIE

P.O. Box 10, Bellingham, Washington 98227-0010 USA

Telephone +1 3606763290 (Pacific Time) · Fax +1 3606471445

SPIE.org

Copyright @ 2015, Society of Photo-Optical Instrumentation Engineers.

Copying of material in this book for internal or personal use, or for the internal or personal use of specific clients, beyond the fair use provisions granted by the U.S. Copyright Law is authorized by SPIE subject to payment of copying fees. The Transactional Reporting Service base fee for this volume is $\$ 18.00$ per article (or portion thereof), which should be paid directly to the Copyright Clearance Center (CCC), 222 Rosewood Drive, Danvers, MA 01923. Payment may also be made electronically through CCC Online at copyright.com. Other copying for republication, resale, advertising or promotion, or any form of systematic or multiple reproduction of any material in this book is prohibited except with permission in writing from the publisher. The CCC fee code is 0277-786X/15/\$18.00.

Printed in the United States of America.

Publication of record for individual papers is online in the SPIE Digital Library.

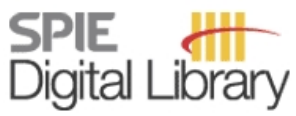

SPIEDigitalLibrary.org

Paper Numbering: Proceedings of SPIE follow an e-First publication model, with papers published first online and then in print. Papers are published as they are submitted and meet publication criteria. A unique citation identifier (CID) number is assigned to each article at the time of the first publication. Utilization of CIDs allows articles to be fully citable as soon as they are published online, and connects the same identifier to all online, print, and electronic versions of the publication. SPIE uses a six-digit CID article numbering system in which:

- The first four digits correspond to the SPIE volume number.

- The last two digits indicate publication order within the volume using a Base 36 numbering

system employing both numerals and letters. These two-number sets start with $00,01,02,03,04$, $05,06,07,08,09,0 A, 0 B \ldots$. OZ, followed by 10-1Z, 20-2Z, etc.

The CID Number appears on each page of the manuscript. The complete citation is used on the first page, and an abbreviated version on subsequent pages. 


\title{
Contents
}

\author{
$\checkmark \quad$ Authors \\ vii Conference Committee
}

\section{SESSION 1 ATMOSPHERIC PROPAGATION}

935403 Power-spectrum requirements in ultraviolet optical wireless networks [9354-2]

935404 Scintillations of a partially coherent beam in a laboratory turbulence: experiment and comparison to theory [9354-3]

935405 Optical channel impact over the PSD of UWB over FSO links [9354-4]

935406 A microwave radiometric method to obtain the average path profile of atmospheric temperature and humidity structure parameters and its application to optical propagation system assessment [9354-5]

\section{SESSION 2 RECEIVER/GROUND TERMINAL}

935407 Array receivers in downlink coherent lasercom [9354-6]

935408 Achieving operational two-way laser acquisition for OPALS payload on the International Space Station [9354-31]

935409 Single-polarization optical low-noise pre-amplified receiver for heavily coded optical communications links [9354-8]

$9354 \mathrm{OA}$ Upwelling radiance at $976 \mathrm{~nm}$ measured from space using the OPALS CCD camera on the ISS [9354-9]

\section{SESSION 3 MODULATION/CODING}

9354 OB Free space optical communication link using a silicon photonic optical phased array [9354-10]

9354 OC Energy efficient rateless codes for high speed data transfer over free space optical channels [9354-11]

\section{SESSION 4 DEMONSTRATIONS I}

9354 OE NASA's optical communications program for 2015 and beyond (Plenary Paper) [9354-201] 
9354 OF Optical payload for lasercomm science (OPALS) link validation during operations from the ISS (Invited Paper) [9354-13]

9354 OG LCT for the European data relay system: in orbit commissioning of the Alphasat and Sentinel 1A LCTs [9354-15]

\section{SESSION 5 DEMONSTRATIONS II}

9354 Ol LEO to ground optical communications from a small satellite platform (Invited Paper) [9354-17]

$93540 \mathrm{~J} T$ The meter-class carbon fiber reinforced polymer mirror and segmented mirror telescope at the Naval Postgraduate School [9354-18]

9354 OK Compact optical gimbal as a conformal beam director for large field-of-regard lasercom applications [9354-19]

\section{SESSION 6 DEMONSTRATIONS III}

$9354 \mathrm{OL}$ Continuous beam divergence control via wedge-pair for laser communication applications [9354-20]

9354 OM Panoramic alignment system for optical wireless communication systems [9354-21]

\section{SESSION 7 POINTING, ACQUISITION, AND TRACKING}

9354 ON Evaluation of developing inertial stabilization unit [9354-22]

935400 Development of a pointing, acquisition, and tracking system for a CubeSat optical communication module [9354-23]

9354 OP Variable acquisition/communication split ratio for lasercom terminals [9354-24]

\section{SESSION 8 LASER TRANSMITTERS}

$93540 Q \quad$ AIGalnN laser diode technology for free-space telecom applications [9354-25]

9354 OR Compact dual channel optical fiber amplifier for space communication applications [9354-26]

9354 OS Compact optical transmitters for CubeSat free-space optical communications [9354-27]

9354 OT Frequency stabilization of laser diodes in an aggressive thermal environment [9354-28]

$9354 \mathrm{OV}$ Object recognition through turbulence with a modified plenoptic camera [9354-30] 


\section{Authors}

Numbers in the index correspond to the last two digits of the six-digit citation identifier (CID) article numbering system used in Proceedings of SPIE. The first four digits reflect the volume number. Base 36 numbering is employed for the last two digits and indicates the order of articles within the volume. Numbers start with 00, 01, 02, 03, 04, 05, 06, 07, 08, 09, OA, OB...0Z, followed by 10-1Z, 20-2Z, etc.

Abib, G. I., 05

Abrahamson, Matthew J., 08, OA, OF

Acharya, U. Sripati, OC

Agrawal, Brij, OJ

Ando, Toshiyuki, ON

Andrews, Kenneth S, OF

Arvizu-Mondragón, A., 05

Bagnasco, John, OJ

Belmonte, Aniceto, 07

Benzi, E., OG

Biswas, Abhijit, 08, 0A, OF

Blanchard, P., OQ

Boćkowski, M., OQ

Cahoy, Kerri, 0O, OS

Caplan, D. O., OS

Cornwell, Donald M., OE

Czernecki, R., OQ

Davis, Christopher C., OM, OV

DeCew, Alan E., OL

DePrenger, Michael J., OB

Drost, Robert J., OM

Efimov, Anatoly, 04

Fernandez, Bautista, OJ

Ferraro, Mike S., OB

Fields, R. A., Ol

Fleet, Erin, $\mathrm{OB}$

Fukushima, Kazuhiko, ON

Goetz, Peter G., OB

Haraguchi, Eisuke, ON

Haruna, Masaki, ON

Heine, F., OG

Henwood-Moroney, L., OR

Hinkley, D. H., Ol

Hinrichs, Keith M., OK, OL

Hosking, P., OR

Janson, S. W., 0 I

Kahn, Joseph M., 07

Kehayas, E., OR

Kelly, A. E., OQ

Kesner, Jessica E., OK

Kingsbury, Ryan, 00, OS

Ko, Jonathan, OV

Kodeki, Kazuhide, ON

Kovalik, Joseph M., OA, OF

Kucharski, R., OQ

Kulkarni, Muralidhar, OC

LaLumondiere, S., 0 I

Lepers, C., 05

Leszczyński, M., OQ
Mahon, Rita, OB

Manning, Robert M., 06

Marona, L., OQ

Martinez, Ty, OJ

Masurkar, Amrita, 09

Meyer, R., OG

Minch, Jeffrey R., 09, 0T

Motzigemba, M., OG

Mühlnikel, G., OG

Muller, M., 05

Najda, S. P., OQ

Narkewich, Lawrence E., OK, OL

Nguyen, Tam, 00

Oaida, Bogdan V., 08, OA, OF

Park, Doe, OB

Pérez-Ramos, A. E., 05

Perlin, P., OQ

Philipp-May, S., OG

Plante, A., OT

Prakash, Geetha, OC

Pruessner, Marcel, OB

Rabinovich, William S., OB

Raptis, Nikos, 03

Riesing, Kathleen, 00

Robertson, A., OR

Roditi, Eugenia, 03

Romeo, Robert, 0J

Rose, T. S., Ol

Roth, Jeffrey M., 09

Rowen, D. W., Ol

Rzasa, John, OM

Sadler, Brian M., OM

Santos-Aguilar, J., 05

Savage, Shelby J., 09, 0T

Scalesse, Vincent, 09, 0T

Seel, S., OG

Shen, Thomas C., OM

Shimizu, Selichi, ON

Sindiy, Oleg, 08

Stampoulidis, L., OR

Stephens, Timothy, OK

Stevens, G., OR

Suski, T., OQ

Suzuki, Jiro, ON

Syvridis, Dimitris, 03

Takahara, Osamu, ON

Targowski, G., OQ

Tröndle, D., OG

Ulmer, Todd G., 09, OP 
Villarreal-Reyes, S., 05

Vyhnalek, Brian, 06

Walther, Frederick G., 09, OP, ОT

Watson, M. A., OQ

Watson, S., $O Q$

Welle, R. P., Ol

Werner, N., Ol

White, H., OQ

Wilcox, Christopher, OJ

Williams, Timothy H., OL

Wisniewski, P., OQ

Wright, Malcolm W., OA, OF

Wu, Chensheng, OV

Zech, H., OG

Proc. of SPIE Vol. $9354935401-6$

Downloaded From: https://www.spiedigitallibrary.org/conference-proceedings-of-spie on 26 Apr 2023 Terms of Use: https://www.spiedigitallibrary.org/terms-of-use 


\title{
Conference Committee
}

\author{
Symposium Chairs
}

Guido Hennig, Daetwyler Graphics AG (Switzerland)

Yongfeng Lu, University of Nebraska-Lincoln (United States)

Symposium Co-chairs

Bo Gu, Bos Photonics (United States)

Andreas Tünnermann, Fraunhofer-Institut für Angewandte Optik und Feinmechanik (Germany) and Friedrich-Schiller-Universtät Jena (Germany)

Conference Chairs

Hamid Hemmati, Facebook Inc. (United States)

Don M. Boroson, MIT Lincoln Laboratory (United States)

Conference Program Committee

Vincent W. S. Chan, Massachusetts Institute of Technology

(United States)

Renny A. Fields, The Aerospace Corporation (United States)

G. Charmaine Gilbreath, U.S. Naval Research Laboratory (United States)

Frank F. Heine, Tesat-Spacecom GmbH \& Company KG (Germany)

Olga Korotkova, University of Miami (United States)

Michael A. Krainak, NASA Goddard Space Flight Center

(United States)

Ronald L. Phillips, Florida Space Institute (United States)

Zoran Sodnik, European Space Research and Technology Center (Netherlands)

Morio Toyoshima, National Institute of Information and Communications Technology (Japan)

Jian Wang, Wuhan National Laboratory for Optoelectronics, Huazhong University of Science and Technology (China)

Alan E. Willner, The University of Southern California (United States)

Shiro Yamakawa, Japan Aerospace Exploration Agency (Japan)

Session Chairs

1 Atmospheric Propagation

Hamid Hemmati, Facebook Inc. (United States) 
2 Receiver/Ground Terminal

Bryan S. Robinson, MIT Lincoln Laboratory (United States)

3 Modulation/Coding

Abhijit Biswas, Jet Propulsion Laboratory (United States)

4 Demonstrations I

Hamid Hemmati, Facebook Inc. (United States)

5 Demonstrations II

Don M. Boroson, MIT Lincoln Laboratory (United States)

6 Demonstrations III

Don M. Boroson, MIT Lincoln Laboratory (United States)

$7 \quad$ Pointing, Acquisition, and Tracking

Abhijit Biswas, Jet Propulsion Laboratory (United States)

8 Laser Transmitters

Bryan S. Robinson, MIT Lincoln Laboratory (United States) 